\title{
Шляхова М.Г., Мамин А.С. \\ Осуществление контроля в области торговли оружием Федеральной службой войск национальной гвардии Российской Федерации
}

Белгородский государственный национальный исследовательский университет (Россия, Белгород)

doi: $10.18411 / \mathrm{j}-05-2021-209$

\section{Аннотация}

Данная статья направлена на рассмотрение общей характеристики контрольных функций в области торговли оружием Федеральной службой войск национальной гвардии Российской. Авторы дают общую характеристику контроля и рассматривают с теоретической точки зрения.

Ключевые слова: оружие, патрон, контроль в области оборота оружия, изъятие оружия.

\section{Abstract}

This article is aimed at considering the general characteristics of the control functions in the field of arms trade by the Federal Service of the National Guard of the Russian Federation. The authors give a general description of the control and consider it from a theoretical point of view.

Keywords: weapons, cartridge, control in the field of arms trafficking, seizure of weapons.

Поскольку любой вид оружия относится к источникам повышенной опасности, его оборот контролируется соответствующими государственными органами, а именно Федеральной службой войск национальной гвардии Российской Федерации. Осуществление проверочных мероприятий за оборотом оружия, патронов и прекращение действия лицензии и разрешения. Контроль за порядком оборота оружия, патронов осуществляется так же Федеральной службой войск национальной гвардии Российской Федерации в следующих случая: выдача, оформлении, продлении срока действия лицензий (разрешений); при проведении проверок соблюдения мер по сохранности оружия юридическими лицами и гражданами, имеющими оружие; при поступлении жалоб, заявлений, сообщений от граждан, учреждений, организаций. Сотрудник Росгвардии, в должностной регламент которого входит контроль над оборотом оружия, при проведении проверочных мероприятий мест хранения оружия, патронов обязан иметь письменное предписание.

Сотрудник Росгвардии в ходе осуществления контроля в области оборота оружия, а также патронов имеет ряд прав. К таким правам относится:

- проведение осмотра оружия в местах его торговли, хранения и производства;

- безвозмездное изъятие и уничтожение оружия, патронов, запрещенных на территории Российской Федерации, за исключением оружия, патронов, реализованных до вступления в силу Федерального закона «Об оружии».

Помимо вышеуказанных случаев изъятия оружия, законодательно определен еще ряд случаев, когда изымается оружие:

- отсутствие лицензий на производство, торговли, приобретение, коллекционирование или экспонирование оружия, или патронов, разрешения на хранение и ношение оружия, разрешений на хранение, использование;

— окончание срока действий вышеуказанных лицензий и разрешений; 
- нарушение юридическими лицами и гражданами определенных законодательно правил приобретения, коллекционирования, экспонирования, передачи, хранения, регистрации, учета, ношения, транспортирования и перевозки, применения оружия до принятия решения по ним;

- выявление кустарно изготовленного или с конструктивными переработками, повлекшие изменения баллистических и другие технических характеристик гражданского, служебного оружия и патронов к ним;

- в случае смерти собственника гражданского оружия до вступления в право собственности наследников имущества, а также смерти гражданина на законных основаниях владевшего служебным или боевым оружием;

- при ликвидации юридического лица.

Федеральная служба войск национальной гвардии Российской Федерации имеет право требовать от юридических лиц и граждан представления устной или письменной информации, а по письменному запросу, данные субъекты обязаны представлять документы или их копии.

Если в результате проверки выявлены нарушения установленных правил, уполномоченный сотрудник Росгвардии вправе давать письменные предписания об устранении нарушений с указанием правил и правовых норм, которые нарушены или не исполнены, конкретные сроки устранения таких нарушений, которые являются обязательными для исполнения гражданами Российской Федерации, должностными лицами и работниками юридических лиц.

Подобные предписания излагаются в форме акта проверки юридических лиц или рапортах, по результатам проверки сохранности оружия, имеющегося у граждан. Если в результате проверки выявлен факт грубого нарушения правил хранения, торговли оружием и патронами, который может повлечь хищение, утрату или неправомерное завладением оружия, уполномоченный сотрудник Росгвардии обязан произвести опечатывание помещений мест торговли, экспонирования оружия и патронов, временно ограничить доступ работников к ним или же запретить ведение торговли до устранения выявленных недостатков. В случае, если невозможно обеспечить сохранность, оружие изымается и передается на ответственное хранение в Росгвардию. По всем фактам нарушений установленных правил реализации оружия выносятся письменные предупреждения лицам, ответственным за его безопасное использование и сохранность, либо гражданам или составляется протокол об административном правонарушении.

Сотрудниками Росгвардии проверяются места, а также объекты хранения оружия, патронов не реже одного раза в квартал с составлением акта. Копия акта вручается руководителю юридического лица под роспись.

Говоря о контрольных функциях Росгвардии, необходимо отметить, что с развитием рыночной экономики и гражданского общества в Российской Федерации своевременно должна совершенствоваться нормативно-правовая база, а также деятельность как контролирующих государственных органов, так и уполномоченных лиц, выступающих от их имени, так как невозможно говорить о дальнейших перспективах развития в сфере обеспечения экономической безопасности РФ.

Следует отметить, что Федеральный закон от 26.12.2008 г. № 294-Ф3 «О защите прав юридических лиц и индивидуальных предпринимателей при осуществлении государственного контроля (надзора) и муниципального контроля» регулирует отношения в области реализации, организации такого контроля и защиты прав юридических лиц, индивидуальных предпринимателей. Такие требования также 
должны учитывать в определенной степени и сотрудники Федеральной службы войск национальной гвардии Российской Федерации.

Осуществляя проверку организации, осуществляющей торговлю оружием (патронами), и имеющей вооруженную охрану помещений, торговых залов, необходимо выяснить наличие договоров на осуществление охраны, законность осуществления конкретными работниками охранных функций с оружием.

Говоря об изъятии и уничтожении оружия и патронов, необходимо отметить, что в случаях, установленных федеральным законодательством, производится изъятие оружия, патронов. Оружие, патроны изымаются Росгвардией. Оружие, патроны, изъятые и проходящие по уголовным делам как вещественные доказательства, передаются по окончании рассмотрения дела в суде. При изъятии оружия, патронов составляется протокол изъятия (акт), в котором указываются тип, вид, модель, калибр, серия и номер изымаемого оружия, а также наименование и количество патронов или в протоколах об административном правонарушении делается запись о досмотре личных вещей или административном задержании в случаях, предусмотренных федеральным законодательством. Порядок составления протокола (акта) установлен КоАП РФ.

Таким образом, при выдаче лицензий на торговлю оружием входит:

- документарная проверка материалов, предоставляемых юридическими лицами при получении государственных услуг;

- обследование помещений, необходимых для выполнения заявленных работ (услуг);

- проведение внеплановых, плановых проверок соблюдения лицензионных условий и требований;

- проверка наличия, организация учета, хранения оружия, патронов, находящихся у юридических лиц и проведение инвентаризации;

— контроль сроков действий выданных лицензий (разрешений) и их аннулирование;

— принятие решения по результатам проверок и контроль за устранением недостатков;

— изъятие оружия, патронов.

$$
\text { *** }
$$

1. Конституция Российской Федерации (принята всенародным голосованием 12.12 .1993 с изменениями, одобренными в ходе общероссийского голосования 01.07.2020) // Официальный интернет-портал правовой информации. - URL: http://www.pravo.gov.ru. (дата обращения:16.04.2021).

2. К Кодекс Российской Федерации об административных правонарушениях от 30.12.2001 № 195-Ф3 (ред. от 04.02.2021) // Собрание законодательства РФ. - 07.01.2002. - № 1 (ч. 1). - ст. 1.

3. Об оружии: Федеральный закон от 13.12.1996 № 150-Ф3 (ред. от 08.12.2020) // Собрание законодательства РФ. - 16.12.1996. - № 51. - ст. 5681.

4. О защите прав юридических лиц и индивидуальных предпринимателей при осуществлении государственного контроля (надзора) и муниципального контроля: Федеральный закон от 26.12.2008 № 294-Ф3 (ред. от 08.12.2020) // Собрание законодательства РФ. - 29.12.2008. - № 52 (ч. 1). - ст. 6249.

5. Об утверждении Административного регламента Федеральной службы войск национальной гвардии Российской Федерации по осуществлению федерального государственного контроля (надзора) за соблюдением законодательства Российской Федерации в области оборота оружия: Приказ Росгвардии от 14.01.2020 № 8 // Официальный интернет-портал правовой информации. URL: http://www.pravo.gov.ru. (дата обращения:30.04.2021).

6. Долгополов А. А. Классификация административно-правовых актов, регламентирующих оборот оружия и взрывчатых веществ / А.А. Долгополов // Административное право и процесс. - 2017. № 1. -С. 12-15.

7. Миронов О. В. О некоторых вопросах совершенствования законодательства об административных правонарушениях в сфере оборота оружия в Российской Федерации / О.В. Миронов // Юридический мир. - 2017. - № 6. - С. 31-34. 